American Journal of Applied Sciences 6 (9): 1675-1681, 2009

ISSN 1546-9239

(C) 2009 Science Publications

\title{
Growth, Feed Utilization and Haematology of Clarias gariepinus (Burchell, 1822) Fingerlings Fed Diets Containing Different Levels of Vitamin C
}

\author{
M. Adunni Adewolu and O. Olakunle Aro \\ Department of Fisheries, Lagos State University, P.M.B. 001, LASU Post Office, \\ Ojo, Lagos, Nigeria
}

\begin{abstract}
Problem statement: In an effort to increase growth, improve feed utilization, reduce stress and prevent certain diseases, a 14 week feeding trial was conducted to determine the effects of different levels of dietary vitamin $\mathrm{C}$ (ascorbic acid) on growth, feed utilization and hematological changes in Clarias gariepinus fingerlings. Approach: Diets were formulated to contain 0, 50, 100, $150,500,1000$ and $1500 \mathrm{mg}$ L-ascorbic acid kg ${ }^{-1}$ of feed contributing $0,0.05,0.10,0.15,0.5,1.0$ and $1.5 \%$ to the formulated diets respectively. Fish of mean weight $10.12 \pm 0.7 \mathrm{~g}$ were fed on experimental diets in triplicate groups. Weight gain of fish fed diet with $0 \%$ of vitamin $\mathrm{C}$ were significantly $(\mathrm{p}<0.05)$ lower than those fed on supplemented vitamin $\mathrm{C}$ diets. Fish fed diet with $1.5 \%$ of vitamin $\mathrm{C}$ showed a significantly $(\mathrm{p}<0.05)$ higher weight gain than fish fed on other diets. However, there were no significant $(\mathrm{p}>0.05)$ differences in weight gain among the fish fed diets containing $0.05,0.10$ and $0.15 \%$ of vitamin C. Generally, fish fed vitamin C supplemented diets showed better growth rate, feed conversion ratio and protein efficiency compared with those without vitamin $\mathrm{C}$ supplementation. Results: The results of hematological analyses of fish showed that red blood cell, white blood cell, haemoglobin concentration and packed cell volume were not significantly ( $p>0.05)$ affected by vitamin $\mathrm{C}$ supplemented diets. Fish fed the vitamin $\mathrm{C}$-free diet begin to show deficiency signs such as erratic swimming, flashing, skin darkening and reduced growth at 12 weeks of feeding trial. Conclusion: This study indicated that $50 \mathrm{mg} \mathrm{kg}^{-1}$ of ascorbic acid is sufficient to prevent C. gariepinus fingerlings from developing clinical symptoms relating to vitamin $\mathrm{C}$ deficiency. A mega dose of $1500 \mathrm{mg} \mathrm{kg}^{-1}$ of ascorbic acid gave maximum growth performance and feed utilization efficiency.
\end{abstract}

Key words: Vitamin C, growth, feed utilization, haematology, Clarias gariepinus

\section{INTRODUCTION}

The African catfish, Clarias gariepinus is the most popular and widely cultivated fish in Nigeria ${ }^{[1]}$. The fingerlings are produced in over $70 \%$ of the functional hatcheries in the country. Most of these catfishes are cultured in tanks under semi-intensive and intensive conditions with high stocking densities. This condition can be very stressful to fish and may hinder their growth and susceptibility to diseases. It is therefore, a standard practice to supplement the diets of intensively grown fish with vitamins. The vitamin nutrition of catfish has been the subject of numerous research reports especially vitamin $\mathrm{C}$ (Ascorbic acid).

Ascorbic acid is an indispensable and multifunctional micronutrient. It plays important roles in improving immune function ${ }^{[2]}$, improving growth ${ }^{[3]}$, providing good health, feed conversion, survival ${ }^{[4]}$, resisting stress ${ }^{[5]}$ and oxidation ${ }^{[6]}$. Several authors have reported that most fish species are highly sensitive to dietary inadequacy of vitamin C. Deficiencies in fish can cause reduced growth rate, deformation of skeletal and cartilaginous tissues, slow wound repairs, increased mortality rate, abnormal pigmentation ${ }^{[7]}$.

It has been found that some animals are able to synthesize certain vitamins in their bodies in quantities sufficient to meet their metabolic needs; these vitamins do not have to be provided in their diets ${ }^{[8]}$ However, some fish species cannot synthesis vitamin $\mathrm{C}$ in their bodies due to lack of gulonolactone oxidase and this enzyme is required for biosynthesis of ascorbic acid from glucose or other simple precursors ${ }^{[9,10]}$, therefore, it must be provided in their diets. Over the years, the ascorbic acid requirements of some commercial important fish species have been reported ${ }^{[11]}$. There has been considerable interest among catfish researchers and catfish producers concerning the use of mega dose level of vitamin $\mathrm{C}$ to enhance disease resistance and improve

Corresponding Author: Adewolu Morenike, A. Department of Fisheries, Lagos State University, P.M.B. 001, LASU Post Office, Ojo, Lagos, Nigeria 
growth of fish. Early evidence indicated that high level of vitamin $\mathrm{C}$ reduced mortality from certain bacteria diseases of catfish. Some catfish producers provide high vitamin $\mathrm{C}$ in feed, which contained more than $1000 \mathrm{mg}$ $\mathrm{kg}^{-1}$ hoping to enhance immune function of fish ${ }^{[8]}$. There is paucity of information on the amount of vitamin $\mathrm{C}$ required by catfish, $C$. gariepinus. This information will assist the fish feed milling industries and small fish farmers that compound their feed locally to know the correct inclusion rate of vitamin $\mathrm{C}$ in their feeds.

This study was therefore designed to evaluate the growth performance, feed utilization, haematology and clinical symptoms of $C$. gariepinus fed on various levels of vitamin $\mathrm{C}$.

\section{MATERIALS AND METHODS}

Experimental diets: Seven iso-nitrogenous diets containing $37 \%$ crude protein were formulated for fingerlings of $C$. gariepinus. Vitamin $\mathrm{C}$ (L-ascorbic acid, AA) was supplied by Titon Company Nigeria Limited, Lagos. This was included at 50, 100, 150, 500, $1000,1500 \mathrm{mg} \mathrm{kg}^{-1}$ feed contributing $0,0.05,0.10$, $0.15,0.5,1.0$ and $1.5 \%$ to the formulated diets of fingerlings of $C$. gariepinus. The feed composition of each diet is presented in Table 1 . The feed ingredients were obtained from Olabosco Agro farm product Company Ltd, where they were ground into fine particles with the aid of attrition mill and mixed. The premix used was devoid of vitamin $C$. Each of the diet was compounded and mixed separated. The mixture was pelleted using an improvised pelleting machine, dried in an oven at $60^{\circ} \mathrm{C}$ to a constant weight.

Feeding trial: Fingerlings of $C$. gariepinus were obtained from Tuns Farm Nigeria Limited, Magon at Ijebu Ode, Ogun State. The fingerlings were sorted to the same average weight. Fish were acclimatized for 2 weeks prior to the start of the experiment, during this period, they were fed on the basal diet without vitamin $\mathrm{C}$ (which later served as control diet). All fish were starved for 24 $\mathrm{h}$ before the commencement of the experiment

The feeding trial was carried out in 21 aquaria tank of $50 \mathrm{~L}$ capacity with depth of $0.50 \mathrm{~m}$. The experiment comprised seven treatments with three replicates each. 15 fingerlings were randomly stocked into each aquarium containing bore-hole water filled to $40 \mathrm{~cm}$ mark and covered with a mosquito net. Each of the diets was fed to fish at $3 \%$ body weight per daily at 9:00 and 18:00 $\mathrm{h}$ for 14 weeks. Fish were weighed every two weeks and feed weight was adjusted accordingly.

Water management: There was $50 \%$ exchange of water in all the tanks daily and continuous aeration was provided to each tank through air stones connected to air compressor. Water temperature, $\mathrm{pH}$, dissolved oxygen and ammonia concentrations in water were monitored everyday except ammonia which was monitored once a week. Temperature was measured using a mercury glass thermometer. $\mathrm{pH}$ was measured with a pH meter (Jenway model 9060) dissolved oxygen with an oxygen meter (Hanna model H1-9142) while ammonia was determined in the laboratory ${ }^{[12]}$. The water temperature varied between $26-28^{\circ} \mathrm{C}, \mathrm{pH}$ ranged from 6.5-7.5, dissolved oxygen levels varied from 4.5-5.5 $\mathrm{mg} \mathrm{L}^{-1}$ while ammonia concentration in water was between $0.03-0.05 \mathrm{mg} \mathrm{L}^{-1}$ throughout the experimental period.

Observations: Fingerlings in each bowl were observed daily for any behavioral and morphological changes, wounds and general well being. All observations and mortalities were recorded.

Chemical analyses of fish samples: Proximate analyses of fish samples were performed using standard $\operatorname{methods}^{[13]}$. Moisture was determined after drying the samples in an oven at $60^{\circ} \mathrm{C}$ until constant weight was obtained. Crude protein $(\mathrm{N} \times 6.25)$ by Kjeldhal method,

Table 1: Percentage composition of experimental diets

\begin{tabular}{lcclcccc}
\hline Ingredients & $0 \%$ Vit. C & $0.05 \%$ Vit. C & $0.10 \%$ Vit. C & $0.15 \%$ Vit. C & $0.50 \%$ Vit. C & $1.00 \%$ Vit. C & $1.5 \%$ Vit. C \\
\hline Maize & 34.25 & 34.20 & 34.15 & 34.10 & 34.00 & 34.00 & 33.86 \\
Soybean & 37.00 & 37.00 & 37.00 & 37.00 & 36.88 & 36.75 & 36.63 \\
Fishmeal & 18.00 & 18.00 & 18.00 & 18.00 & 18.00 & 18.00 & 18.00 \\
Wheat offal & 8.00 & 8.00 & 8.00 & 8.00 & 7.88 & 7.50 & 7.25 \\
Ca $\left(\mathrm{Po}_{4}\right)_{2}$ & 1.00 & 1.00 & 1.00 & 1.00 & 1.00 & 1.00 & 1.00 \\
Vitamin C & 0.00 & 0.05 & 0.10 & 0.15 & 0.50 & 1.00 & 1.50 \\
Premix* & 0.50 & 0.50 & 0.50 & 0.50 & 0.50 & 0.50 & 0.50 \\
Palm oil & 1.00 & 1.00 & 1.00 & 1.00 & 1.00 & 1.00 & 1.00 \\
Common salt $(\mathrm{NaCl})$ & 0.25 & 0.25 & 0.25 & 0.25 & 0.25 & 0.25 & 0.25 \\
\hline
\end{tabular}

*: Premix (Vitamin $\mathrm{C}$ free) mg/100 g diet supplied by Animal care, Limited, Lagos Nigeria; Thiamine $\left(\mathrm{B}_{1}\right) 2.5 \mathrm{mg}$; Riboflavin (B), $2.5 \mathrm{mg}$; Pyridoxine $2.0 \mathrm{mg}$; Pantothenic acid $5.0 \mathrm{mg}$; Inositol $3 \mathrm{mg}$; Folic acid, $0.75 \mathrm{mg}$, Para-amino benzoic $2.5 \mathrm{mg}$; Choline $200 \mathrm{mg}$; Niacin $10.0 \mathrm{mg}$; Cycobalamin ( $\left.\mathrm{B}_{12}\right) 10.0 \mathrm{mg}$; Menadione (k) $2.0 \mathrm{mg}$; Minerals; CaHP04 $727.8 \mathrm{mg} ; \mathrm{mg} \mathrm{SO}$, $1275 \mathrm{mg}$; KCL $60 \mathrm{mg} ; \mathrm{FeSO}_{4} 50.0 \mathrm{mg} ; \mathrm{ZnSO}_{4} 250$ $\mathrm{mg} ; \mathrm{Mn}_{2} \mathrm{SO}_{4} 5.5 \mathrm{mg} ; \mathrm{CuSO}_{4} 2.5 \mathrm{mg} ; \mathrm{CoSO}_{4} 0.79 \mathrm{mg} ; \mathrm{Caclo}_{3} 0.48 \mathrm{mg} ; \mathrm{Crcl}_{3} 0.3 \mathrm{mg}$ 
crude fiber after acid/base digestion process, crude lipid was done by ether extraction using soxhlet, ash content in muffle furnace at $600^{\circ} \mathrm{C}$ for $12 \mathrm{~h}$. Nitrogen Free Extract (NFE) was computed by taking the sum values for crude protein, crude lipid, crude fiber, total ash and subtracting this from 100 .

Haematological analyses: At the end of the experiment, about $1 \mathrm{~mL}$ of blood was collected from fish anaesthetized by MS-222, (Sandoz, Basel, Switzerland). Fish were cut at the caudal peduncle and blood was collected in coded $1.5 \mathrm{~mL}$ heparinized plastic tubes, stored on ice and centrifuged within $30 \mathrm{~min}$ of their collection. The blood samples were analyzed at the Chemical Pathology Department Olabisi Onabanjo University Teaching Hospital, Shagamu, Ogun State within $2 \mathrm{~h}$ of collections. The Packed Cell Volume (PCV) of each of the blood samples was determined in the laboratory using the hematocrit reader method ${ }^{[14]}$ and values expressed in percentage.

The Haemoglobin concentration $(\mathrm{Hb})$ of each blood samples was determined in the laboratory ${ }^{[14]}$. The $\mathrm{Hb}$ concentration in grams/deciliter was calculated using a standardized graph. The Red Blood Cell (RBC) and the White Blood Cell (WBC) count of each of the blood sample was determined in the laboratory ${ }^{[14]}$.

Calculations and statistical analysis: Mean Weight Gain (WTG), Specific Growth Rate (SGR), Percentage Weight Gain (PWG), Protein Efficiency Ratio (PER), Feed Intake (FI), Protein Intake (PI) and Feed Conversion Ratio (FCR) were calculated according to the following:

$$
\mathrm{WTG}=\begin{aligned}
& \text { Mean final body weight-mean initial body } \\
& \text { weight }
\end{aligned}
$$

PWG $=\frac{\text { Mean weight gain }}{\text { Mean initial gain }} \times 100$

\begin{tabular}{|c|c|c|}
\hline \multicolumn{3}{|l|}{ Where: } \\
\hline $\mathrm{T}$ & $=$ & Represents trial duration (day) \\
\hline $\mathrm{W}_{\mathrm{f}}$ and $\mathrm{W}_{\mathrm{i}}$ & $=$ & $\begin{array}{l}\text { Represent mean final and initial } \\
\text { weights }(\mathrm{g}) \text {, respectively }\end{array}$ \\
\hline \multirow{2}{*}{ FCR } & \multirow{2}{*}{$=$} & Weight of dry feed $(\mathrm{g})$ \\
\hline & & Weight gain of fish $(\mathrm{g})$ \\
\hline \multirow{2}{*}{ PER } & & Gain in weight of fish $(\mathrm{g})$ \\
\hline & & Protein Int ake $(\mathrm{PI})(\mathrm{g})$ \\
\hline
\end{tabular}

$\operatorname{SRG}(\mathrm{BW} \% /$ day $)=\frac{\left(\log _{\mathrm{e}} \mathrm{W}_{\mathrm{f}} \log _{\mathrm{e}} \mathrm{W}_{\mathrm{i}} \times 100\right.}{\mathrm{T}}$
PI $=$ Feed Intake $(\mathrm{FI}) \mathrm{X} \%$ protein in diet

$\mathrm{F} 1=3 \%$ Body weight of fish per day

Survival $(\%)=\mathrm{S} 1 / \mathrm{S} 2 \times 100$

S1 $=$ No. of fish at the end of experiment

S2 $=$ No. of fish at the beginning of experiment

Data were subjected to one way analysis of variance (ANOVA) to determine significance between mean values using SAS ANOVA procedure (statistical analysis system 1995).

Duncan's multiple range test ${ }^{[15]}$ was used to compare differences among means ${ }^{[16]}$ Significant level was chosen at $\mathrm{p}<0.05$.

\section{RESULTS}

Proximate composition of experimental diets: The results of the proximate composition of experimental diets are presented in Table 2. All the diets were isonitrogenous. The levels of crude lipid and crude fiber were between $4.11-6.61 \%$ and $1.27-2.18 \%$ respectively. Nitrogen free extract ranged from 46.94-48.74\%.

Morphological and behavioral observations: Fish fed on vitamin $\mathrm{C}$ free diet $(0 \%)$ showed certain morphological and behavioral changes from 12 weeks of feeding. Some fish were shocked during the water exchange and during weighing exercise. These fish were easily shocked when disturbed. They hid at the corners of aquaria. They exhibited erratic swimming and some of them lost balance and showed erratic swimming. Dark skin coloration was also observed. However, fish given vitamin C-supplemented feed showed normal behavior and no external abnormalities were observed.

Growth and feed utilization parameters: Growth and feed utilization parameters are presented in Table 3. Fish fed diet without ascorbic acid supplementation showed significantly lower percentage weight gain and specific growth rate $(\mathrm{p}<0.05)$ compared with those fed diets supplemented with various levels of ascorbic acids.

There were no significant differences in the percentage weight gain and specific growth rate of fish fed on diets containing lower concentrations of ascorbic acids $(0.05,0.10$ and $0.15 \%)$ compared with fish fed on diets containing mega doses of ascorbic acid (0.5, 1.0 and $1.5 \%)$ which showed significantly $(\mathrm{p}<0.05)$ higher values.

Fish given the diet without vitamin $\mathrm{C}$ supplementation had higher FCR $(\mathrm{p}<0.05)$ compared with those fed diets containing vitamin $\mathrm{C}$ supplements. 
Am. J. Applied Sci., 6 (9): 1675-1681, 2009

Table 2: Proximate composition of experimental diets (\%)

\begin{tabular}{lcccccrr}
\hline Parameters & $0 \%$ VitC & $0.05 \%$ VitC & $0.10 \%$ VitC & $0.15 \%$ VitC & $0.50 \%$ VitC & $1.00 \%$ VitC & $1.5 \%$ VitC \\
\hline Crude protein & 37.20 & 37.08 & 36.90 & 37.01 & 37.02 & 37.45 & 37.36 \\
Crude lipid & 4.11 & 5.38 & 5.09 & 5.70 & 4.11 & 6.29 & 6.61 \\
Crude fiber & 2.18 & 1.87 & 1.90 & 1.87 & 2.18 & 1.27 & 1.80 \\
Total ash & 7.95 & 7.38 & 8.28 & 6.97 & 7.95 & 7.78 & 7.29 \\
Moisture & 10.13 & 9.39 & 9.00 & 9.05 & 10.13 & 9.80 & 10.18 \\
NFE & 48.56 & 48.29 & 47.83 & 48.45 & 48.74 & 47.21 & 46.94 \\
\hline
\end{tabular}

NFE: Nitrogen Free Extract. VitC: Vitamin C

Table 3: Growth and Feed Utilization of Clarias gariepinus fed on diets containing various levels of Vitamin C

\begin{tabular}{|c|c|c|c|c|c|c|c|}
\hline Parameters & $0 \%$ VitC & $0.05 \% \mathrm{VitC}$ & $0.10 \%$ VitC & $0.15 \%$ VitC & $0.50 \% \mathrm{VitC}$ & $1.00 \% \mathrm{VitC}$ & $1.5 \%$ VitC \\
\hline Initial weight (g) & $10.19 \pm 0.18$ & $10.15 \pm 0.23$ & $10.12 \pm 0.23$ & $10.16 \pm 0.18$ & $10.21 \pm 0.90$ & $10.170 \pm 0.15$ & $10.15 \pm 0.15$ \\
\hline Final weight (g) & $98.15 \pm 2.35^{\mathrm{a}}$ & $140.87 \pm 1.44^{b}$ & $141.83 \pm 1.89^{b}$ & $142.43 \pm 2.67^{b}$ & $162.67 \pm 2.26^{\mathrm{c}}$ & $172.370 \pm 2.27^{\mathrm{d}}$ & $230.50 \pm 5.20^{\mathrm{e}}$ \\
\hline Weight gain (g) & $87.96 \pm 1.35^{\mathrm{a}}$ & $130.72 \pm 1.64^{\mathrm{b}}$ & $131.71 \pm 1.67^{b}$ & $132.28 \pm 2.85^{\mathrm{b}}$ & $152.46 \pm 2.30^{\mathrm{c}}$ & $162.200 \pm 2.87^{\mathrm{d}}$ & $220.35 \pm 5.13^{\mathrm{e}}$ \\
\hline Weight gain $(\%)$ & $863.67 \pm 26.65^{\mathrm{a}}$ & $1288.51 \pm 44.70^{\mathrm{b}}$ & $1301.70 \pm 13.09^{\mathrm{b}}$ & $1302.94 \pm 50.17^{\mathrm{b}}$ & $1493.88 \pm 31.73^{\mathrm{c}}$ & $1.595 \pm 52.14^{\mathrm{d}}$ & $2171.02 \pm 45.21^{\mathrm{e}}$ \\
\hline Specific growth rate & $2.31 \pm 0.03^{\mathrm{a}}$ & $2.68 \pm 0.32^{\mathrm{b}}$ & $2.69 \pm 0.01^{\mathrm{b}}$ & $2.69 \pm 0.04^{\mathrm{b}}$ & $2.83 \pm 0.02^{\mathrm{c}}$ & $2.890 \pm 0.03^{\mathrm{d}}$ & $3.19 \pm 0.02^{\mathrm{e}}$ \\
\hline Feed intake $(\mathrm{g})$ & $150.41 \pm 0.16^{\mathrm{a}}$ & $183.49 \pm 0.77^{\mathrm{b}}$ & $185.36 \pm 2.29^{b}$ & $211.45 \pm 1.62^{\mathrm{c}}$ & $244.63 \pm 2.26^{\mathrm{d}}$ & $261.940 \pm 1.96^{\mathrm{e}}$ & $302.96 \pm 5.65^{\mathrm{f}}$ \\
\hline Protein intake & $55.65 \pm 0.06^{\mathrm{a}}$ & $67.89 \pm 0.29^{\mathrm{b}}$ & $68.58 \pm 0.85^{b}$ & $78.24 \pm 0.60^{\mathrm{c}}$ & $90.52 \pm 0.84^{\mathrm{d}}$ & $96.920 \pm 0.73^{\mathrm{e}}$ & $112.10 \pm 2.09^{\mathrm{f}}$ \\
\hline Feed conversion $r$ & $1.71 \pm 0.05^{\mathrm{a}}$ & $1.40 \pm 0.02^{\mathrm{b}}$ & $1.41 \pm 0.003^{\mathrm{b}}$ & $1.60 \pm 0.02^{\mathrm{c}}$ & $1.61 \pm 0.03^{\mathrm{c}}$ & $1.610 \pm 0.02^{\mathrm{c}}$ & $1.37 \pm 0.01^{\mathrm{d}}$ \\
\hline Protein efficiency ratio & $1.58 \pm 0.04^{\mathrm{a}}$ & $1.93 \pm 0.02^{\mathrm{b}}$ & $1.92 \pm 0.004^{b}$ & $1.69 \pm 0.02^{\mathrm{c}}$ & $1.69 \pm 0.03 \mathrm{c}$ & $1.960 \pm 0.01^{\mathrm{d}}$ & $1.78 \pm 0.15^{\mathrm{e}}$ \\
\hline Survival $(\%)$ & $62.22 \pm 3.85^{\mathrm{a}}$ & $95.56 \pm 3.85^{b}$ & $97.78 \pm 3.85^{b}$ & $95.56 \pm 3.85^{b}$ & $95.56 \pm 3.85^{b}$ & $97.78 \pm 3.85^{b}$ & $95.56 \pm 3.85^{\mathrm{b}}$ \\
\hline
\end{tabular}

Mean values in the same row with different superscript are significantly different $(\mathrm{p}<0.05)$. VitC: Vitamin C

Table 4: Proximate body composition of Clarias gariepinus fingerlings fed diets with various levels of Vitamin C

\begin{tabular}{lccccccccc}
\hline Parameters & Initial & $0 \%$ VitC & $0.05 \%$ VitC & $0.10 \%$ VitC & $0.15 \%$ VitC & $0.5 \%$ VitC & $1.0 \%$ VitC & $1.5 \%$ VitC & SEM \\
\hline Crude protein & 67.84 & 68.83 & 70.45 & 70.71 & 69.61 & 68.05 & 68.33 & 68.50 & 0.74 \\
Crude lipid & $5.00 \mathrm{~b}$ & $4.00^{\mathrm{a}}$ & $4.97^{\mathrm{b}}$ & $5.43^{\mathrm{c}}$ & $5.60^{\mathrm{c}}$ & $5.54^{\mathrm{c}}$ & $7.33^{\mathrm{d}}$ & $7.50^{\mathrm{d}}$ & 0.24 \\
Crude fiber & 1.24 & 1.26 & 1.18 & 1.17 & 1.17 & 1.18 & 1.20 & 1.21 & 0.03 \\
Total ash & 17.36 & 17.05 & 17.79 & 17.45 & 17.41 & 17.46 & 16.70 & 17.00 & 0.63 \\
NFE & 8.56 & 8.86 & 8.61 & 8.26 & 6.80 & 7.77 & 6.44 & 5.79 & 0.69 \\
DM & 92.30 & 92.67 & 92.41 & 92.75 & 92.69 & 92.75 & 93.44 & 93.47 & 0.30 \\
\hline
\end{tabular}

Mean values in the same row with different superscript are significantly different $(\mathrm{p}<0.05)$. VitC: Vitamin $\mathrm{C}$

Table 5: Haemotological parameters of fingerlings of Clarias gariepinus fed on various levels of vitamin C

\begin{tabular}{|c|c|c|c|c|c|c|c|c|c|}
\hline Parameters & Initial & $0 \%$ VitC & $0.05 \%$ VitC & $0.1 \%$ VitC & $0.15 \%$ VitC & $0.5 \% \mathrm{VitC}$ & $1.0 \% \mathrm{VitC}$ & $1.5 \%$ VitC & SEM \\
\hline RBC (\%) & 86.33 & 86.00 & 86.97 & 87.67 & 87.33 & 86.90 & 87.33 & 87.00 & 0.89 \\
\hline WBC (\%) & 53.35 & 54.00 & 54.33 & 55.67 & 55.33 & 55.67 & 56.00 & 56.50 & 0.99 \\
\hline $\mathrm{Hb}\left(\mathrm{g} \mathrm{dL}^{-1}\right)$ & 8.66 & 8.62 & 9.08 & 9.00 & 8.54 & 9.04 & 8.97 & 8.65 & 0.35 \\
\hline PCV (\%) & 35.43 & 35.33 & 36.67 & 35.00 & 34.86 & 36.55 & 36.33 & 35.67 & 0.55 \\
\hline
\end{tabular}

RBC: Red Blood Cell count; WBC: White Blood Cell count; Hb: Haemoglobin concentration; PCV: Packed Cell Volume VitC: Vitamin C

PER value was lowest in diet without vitamin $\mathrm{C}$ supplementation compared with other diets that were supplemented with vitamin $\mathrm{C}$.

The general trend is that fish fed diet without vitamin $\mathrm{C}$ supplementation had the lowest growth and performance followed by fish fed diets containing lower doses of vitamin $\mathrm{C}(0.05,0.10$ and $0.15 \%)$ and the highest growth performance was exhibited with fish fed diets containing the largest (mega) dose of vitamin C (1.5\%).

Body composition: The results of carcass analyses of fish fed on diets containing various levels of vitamin $\mathrm{C}$ are shown in Table 4. The percentage crude protein, crude fiber and total ash were not affected by dietary treatments. However, fish fed diet without vitamin $\mathrm{C}$ supplementation $(0 \%)$ had the lowest percentage of body lipid compared with fish fed on other diets with vitamin $\mathrm{C}$ supplements.

Blood components: The results of blood analysis of fish fed diets containing various levels of vitamin $\mathrm{C}$ are presented in Table 5. The hematocrit and haemoglobin values are similar among groups $(\mathrm{p}>0.05)$. The red and white blood cell counts were not different $(p>0.05)$ among treatments.

\section{DISCUSSION}

In the present study, growth, feed utilization and survival of $C$. gariepinus improved with the inclusion of vitamin $\mathrm{C}$ in fish diets. Fish fed vitamin Csupplemented diets showed better growth, feed utilization efficiencies and survival compared with those without supplementation. This is in agreement 
with other reports ${ }^{[3,17-20]}$. The reduction in growth performance of fish fed the control diet is an indication that ascorbic acid has an effect on growth of fish as originally pointed $^{[21]}$.

It was observed in this study that increasing the concentration of vitamin $C$ from $50-150 \mathrm{mg}$ gives no significant difference $(\mathrm{p}<0.05)$ in terms of growth performance. This observation is in line with previous studies $^{[3]}$. It has been reported that low vitamin $\mathrm{C}$ activity levels are sufficient for optimum growth and feed conversion for cultured fish ${ }^{[10]}$. However, when fish were fed diets containing mega doses of vitamin $\mathrm{C}$ $(500-1500 \mathrm{mg})$ there were significant $(\mathrm{p}<0.05)$ increase in the growth performance compared with fish fed diets containing lower doses of vitamin C (50-150 mg). Generally, the diet supplemented with $1500 \mathrm{mg} \mathrm{kg}^{-1}$ gave the best growth performance compared with other diets $^{[8]}$. It has been reported that mega doses of vitamin $\mathrm{C}$ increased growth, survival and immune system of fish. It was reported that some catfish producers include up to $2,000 \mathrm{mg} \mathrm{kg}^{-1}$ of vitamin $\mathrm{C}$ in catfish feed to enhance their immune function and growth ${ }^{[8]}$.

A number of previous studies have shown the beneficial effects of high vitamin $\mathrm{C}$ intake in enhancing resistance to stress and improving growth ${ }^{[3,5,8]}$. Clinical symptoms of ascorbic acid deficiency such as dark skin coloration, reduced growth rate, flashing and erratic swimming were observed in fish fed un-supplemented vitamin C diet (control) after 12 weeks of feeding trial. The time of occurrence of deficiency symptoms in fish fed diet devoid of vitamin $\mathrm{C}$ suggest that $C$. gariepinus fingerlings were able to depend on stored ascorbate for 12 weeks excluding the 2 weeks of acclimation period. This time is longer than the 9 weeks observed for Heterobranchus longifilis ${ }^{[20]}$. The reasons for earlier occurrence of symptoms in $H$. longifilis may be attributed to higher stocking rate and the size of fish used. It was found that 9 weeks were sufficient to develop deficiency symptoms in smaller fishes fed ascorbate-free diet ${ }^{[22]}$. However, bigger fish did not show any deficiency sign after 18 weeks $^{[23]}$. Some workers observed that young fish need to increase their mass about 10 times to develop deficiency symptoms $^{[24]}$.

Different signs of deficiency symptoms in terms of behavior, dark skin coloration, reduced growth, hemerrage, have been reported, in catfishes such as Heterobranchus longifilis ${ }^{[19,20]}$; Clarias gariepinus ${ }^{[25]}$; channel catfish $^{[26,27]}$; hybrid Clarias ${ }^{[3]}$. There are similar reports on vitamin $\mathrm{C}$ deficiency in other kinds of fish such as rainbow trout ${ }^{[22]}$, hybrid tilapia ${ }^{[28]}$ and Seabrass $^{[29]}$. However, the usual vitamin C deficiency signs, such as scoliosis and lordosis were not observed in this study.

Haemoglobin concentration, red blood cell, white blood cell and packed cell volume values of fish in the present study were not significantly $(p>0.05)$ affected by vitamin $\mathrm{C}$ supplementation. This is in line with previous reports that blood parameters of fish fed on diets without vitamin $\mathrm{C}$ were not significantly different from that of the supplemented diets ${ }^{[3]}$. The result, however, conflicts with other results ${ }^{[20]}$ that blood parameters were elevated in Heterobranchus longifilis given dietary vitamin $\mathrm{C}$ supplementation. The lower percentage of body lipid observed in fish fed on vitamin $\mathrm{C}$ free diet compared with fish fed on vitamin $\mathrm{C}$ diets might be as a result of the erratic swimming, flashing and other restless activities of fish which made use of body lipid as energy.

\section{CONCLUSION}

In conclusion, the results of this study show that a minimum of $50 \mathrm{mg} \mathrm{kg}^{-1}$ of ascorbic acid is sufficient for Clarias gariepinus fingerlings not to develop clinical symptoms relating to vitamin $\mathrm{C}$ deficiency. A mega dose of $1500 \mathrm{mg} \mathrm{kg}^{-1}$ of ascorbic acid gave the best growth performance and feed utilization efficiency. Clarias gariepinus fingerlings have a latency period of 12 weeks before showing vitamin $\mathrm{C}$ deficiency symptoms.

\section{REFERENCES}

1. Awa, J.N. and W.O. Alegbeleye, 1991. Occurrence and treatment of cracked-skull disease affecting Clarias spp. in homestead ponds in Nigeria. J. Fish Dis., 14: 431-505. DOI: 10.1111/j.13652761.1991.tb00599.x

2. Hardie, L.J., T.C. Fletcher and C.J. Secombes, 1991. The effect of dietary vitamin C on the immune response of the Atlantic salmon (Salmo salar L.). Aquaculture, 95: 201-214. http://cat.inist.fr/?aModele=afficheN\&cpsidt=5329817

3. Boonyaratpalin, M. and W. Phromkunthong, 2001. Bioavailability of ascorbyl phosphate calcium in hybrid catfish, Clarias macrocephalus (Grunther) $\times$ Clarias gariepinus (Burchell) feed. Aquac. Res., 32: 126-134.

http://grande.nal.usda.gov/ibids/index.php?mode2= detail\&origin=ibids_references\&therow $=477795$

4. Khajarern, J. and S. Khajarern, 1997. Stability and bioavailability of vitamin C-glucose in Clarias hybrid catfish (Clarias gariepinus $\times$ Clarias macrocephalus). Aquaculture, 151: 219-224. http://cat.inist.fr/?aModele $=$ afficheN\&cpsidt=2761951 
5. Henrique, M.M.F., E.F. Gomes, M.F. Gouilou-Coustans, A. Oliva-Teles and S.J. Davies, 1998. Influence of supplementation of practical diets with vitamin $\mathrm{C}$ on growth and response to hypoxic stress of seabream, Sparus aurata. Aquaculture, 161: 415-426. DOI: 10.1016/S0044-8486(97)00289-5

6. Shiau, S.Y. and C.Y. Hsu, 2002. Vitamin E sparing effect by dietary Vitamin $\mathrm{C}$ in juvenile hybrid tilapia, Oreochromis niloticus $\times O$. aureus. Aquaculture, 210: 335-342. DOI: 10.1016/S00448486(01)00853-5

7. Xie, Z. and C. Niu, 2006. Dietary ascorbic acid requirement of juvenile ayu (plecoglossus altivelis). Aquac. Nutr., 12: 151-156. DOI: 10.1111/j.13652095.2006.00395.x

8. Robinson, E.H., 2003. Catfish vitamin nutrition. http://msucares.com/pubs/bulletins/b1078frames.htm

9. Dabrowski, K., 2001. History, Present and Future of Ascorbic Acid Research in Aquatic Organism. In: Ascorbic and in Aquatic Organisms: Status and Perspectives, Dabrowski, K. (Ed.). CRC Press, Boca Raton, ISBN: 0849398819, pp: 225-277.

10. O'keefe, T., 2001. Ascorbic acid and stable ascorbate esters as sources of vitamin $\mathrm{C}$ in aquaculture feeds. ASA Tech. Bull., 48: 1-10. http://www.soyaqua.org/pdf/VitCSources.pdf

11. Halver, J.E., 2002. The Vitamins. In: Fish Nutrition, Halver, J.E. and R.W. Hardy (Eds.), 3rd Edn., Academic Press, San Diego, CA., ISBN: 6-12319652-3 pp: 824

12. Greenberg, A., 1985. Standard Methods for the Examination of Water and Wastewater. 19th Edn., American Public Health Association, Washington DC., USA., ISBN: 0875531318, pp: 1268.

13. Helrich, K., 1990. Official Method of Analysis of the Association of Official Analytical Chemists. 15th Edn., Association of Official Analytical Chemists, Arlington, VA., ISBN: 0935584420, pp: 614.

14. Dacie, S.I.V. and S.M. Lewis 2006. Practical Haematology. 10th Edn., Churchill Livingstone, London. ISBN: 13:978-0-443-06660-3, pp: 736.

15. Duncan, D.B., 1955. Multiple ranges and multiple T-test. Biometrics, 11: 1-42. http://www.jstor.org/pss/3001478

16. Snedecor, G.W. and W.G. Cochran, 1980. Statistical Methods. 7th Edn., The Iowa State University Press, Ames, USA., ISBN: 0813815606, pp: 507.
17. Gbadamosi, O.K., E.A. Fasakin and O.T. Adebayo, 2006. Evaluation of dietary ascorbic acid supplementation in practical diets for African Catfish Clarias gariepinus (Burchell, 1822) Fingerlings. J. Fish. Int., 1: 8-11. http://www.medwelljournals.com/fulltext/jfi/2006/ 8-11.pdf

18. Gbadamosi, K. and J. Daramola, 2007. Quantitative requirements of dietary ascorbic acid supplementation in the diets of African Catfish Clarias gariepinus (Burchell 1822) fingerlings. J. Anim. Vet. Adv., 6: 90-93. http://medwelljournals.com/fulltext/java/2007/90-93.pdf

19. Ibiyo, L.M.O., C.T. Madu and S.S. Eze, 2006. Effects of vitamin $\mathrm{C}$ supplementation on the growth of Heterobranchus longifilis fingerlings. Ach. Anim. Nutr. J., 60: 325-332. http://cat.inist.fr/?aModele $=$ afficheN\&cpsidt $=1795$ 6307

20. Ibiyo, L.M.O., J.O. Atteh, J.S. Omotosho and C.T. Madu, 2007. Vitamin C (ascorbic acid) requirements of Heterobranchus longifilis fingerlings. Afr. J. Biotech., 6: 1559-1567. http://www.bioline.org.br/abstract?id=jb07273\&lan $\mathrm{g}=\mathrm{en}$

21. Ram, M.M., 1966. Growth rate and protein utilization in vitamin C deficiency. Indian J. Med. Res., 541: 946-970. http://www.ncbi.nlm.nih.gov/pubmed/5976998

22. Dabrowski, K., M. Matusiewicz and J.H. Bloom, 1994. Hydrolysis, absorption and bioavailability of ascorbic acid esters in fish. Aquaculture, 124: 169-192. http://cat.inist.fr/?aModele $=$ afficheN\&cpsidt $=4193$ 381

23. Matusiewicz, M., K. Dabrowski, L. Volker and K. Matusiewicz, 1995. Ascrobate polyphosphate as a bioavailable vitamin $\mathrm{C}$ source in juvenile rainbow trout: Tissue saturation and compartmentalization model J. Nutr., 125: 3055-3061. http://jn.nutrition.org/cgi/content/abstract/125/12/3 055

24. Halver, J.E., R.R. Smith, B.M. Tolbert and E.M. Baker, 1975. Utilization of ascorbic acid in fish. Ann. N. Y. Acad. Sci., 258: 81-102. http://www.ncbi.nlm.nih.gov/pubmed/1060421

25. Eya, J.C. and B.O. Mgbenka, 1990. Ascorbic acid (vitamin C) requirement of African Catfish, Clarias gariepinus (Tengelo 1984). J. Aquat. Sci., 5: 65-75.

http://www.fao.org/agris/search/display.do?f=./199 4/v2011/NG9400058.xml;NG9400058 
26. Lim, C. and R.T. Lovell, 1978. Pathology of vitamin $\mathrm{C}$ deficiency syndrome in Channel catfish, (Ictalurus punctatus). J. Nut., 108: 1137-1146. http://jn.nutrition.org/cgi/content/abstract/108/7/1137

27. Miyasaki, T., J.A. Plumb, Y.P. Li and R.T. Lovell, 1985. Histopathology of broken-back syndrome in channel catfish. J. Fish Biol., 26: 647-655. DOI: 10.1111/j.1095-8649.1985.tb04305.x

28. Shiau, S.Y. and T.S. Hsu, 1995. L-ascorbyl-2sulfate has equal antiscorbutic activity as Lascorbyl-2-monophosphate for tilapia. Oreochromis niloticus $\times$ O. aureus. Aquaculture, 133: 147-157.

http://cat.inist.fr/?aModele $=$ afficheN\&cpsidt=3590346
29. Phromkunthong, W., M. Boonyaratpalin and V. Storch, 1997. Different concentrations of ascorbyt -2monophosphate-magnesium as dietary sources of vitamin $\mathrm{C}$ for sea bass, Lates calcarifer. Aquaculture, 151: 225-243. DOI: 10.1016/S00448486(96)01489-5 